\title{
Evaluation of asymptomatic subjects with low forced expiratory ratios $\left(\mathrm{FEV}_{1} / \mathrm{VC}\right)$
}

\author{
S Kivity, A Solomon, Y Schwarz, I Trajber, M Topilsky
}

\begin{abstract}
Background - Heightened bronchial hyperreactivity is frequently associated with airflow limitation, atopy, or cigarette smoking. The purpose of this study was to evaluate healthy subjects with significantly low values of forced expiratory volume in one second/vital capacity \% $\left(F E V_{1} / V C \%\right)$ by measuring their airway response to exercise and methacholine challenge, compared with a control group with normal spirometric values. Methods - Eighty four healthy subjects with significantly low flow rates (group A, FEV $_{1} /$ VC\% <2 SD $\%$ predicted) were evaluated and compared with 37 subjects with normal flow rates (group B). Static lung volumes, spirometric tests, exercise, and methacholine challenges were performed.
\end{abstract}

Results - Lung volumes were normal for both groups. Mean $\mathrm{FEV}_{1} / \mathrm{VC} \%$ was $69 \%$ for group $A$ and $82 \%$ for the control group. Salbutamol improved baseline $\mathrm{FEV}_{1}$ in eight subjects in group $A$ (mean $15 \%$ ), while methacholine induced a drop in $F E V_{1}$ in 12 subjects. The dose-response curve to methacholine reached a plateau in all the responders. None of the subjects in the control group improved their baseline $\mathrm{FEV}_{1} / \mathrm{VC} \%$ to salbutamol, but three showed bronchial hyperreactivity similar to those in group $A$.

Conclusions - Bronchial hyperreactivity does not occur more often in asymptomatic subjects with mildly low $\mathrm{FEV}_{1}$ / VC\% so these subjects do not require special investigations for airway disease.

Institute of

(Thorax 1994;49:554-556)

Pulmonary and

Allergic Diseases,

Allergy Unit, Tel-Aviv

Sourasky Medical

Center and Sackler

Faculty of Medicine,

Tel-Aviv University,

Israel

S Kivity

A Solomon

Y Schwarz

I Trajber

M Topilsky

Reprint requests to: Dr S Kivity, Allergy Unit, Institute of Pulmonary and Allergic Diseases, Ichilov Hospital, 6 Weizman Street, Tel-Aviv 64239, Israel.

Received 19 August 1993 Returned to authors 29 October 1993

Revised version received

15 December 1993

Accepted for publication

22 February 1994
Most studies performed on asthmatic subof bronchial hyperreactivity and the baseline airway calibre. ${ }^{4-6}$ Ryan $e t$ al showed that asthmatic patients may have a moderate or severe increase in bronchial hyperreactivity $\left(\mathbf{P C}_{20}\right.$ $<2 \mathrm{mg} / \mathrm{ml}$ to histamine) when their $\mathrm{FEV}_{1}$ is jects report no correlation between the extent within $10 \%$ of maximum. In subjects with symptomatic airflow limitation bronchial hyperreactivity is a concomitant finding. We occasionally encounter young asymptomatic subjects with a low ratio of $\mathrm{FEV}_{1}$ to vital capacity $\left(\mathrm{FEV}_{1} / \mathrm{VC} \%\right)$, the significance of which is not entirely clear. We therefore measured the airway response to exercise and methacholine of healthy subjects with a low $\mathrm{FEV}_{1} / \mathrm{VC} \%$ and compared the results with a control group.

\section{Methods}

Eighty four subjects aged 17-39 (mean 24) years (group A) were included on the basis of two spirometric studies (including one in our laboratory) showing $\mathrm{FEV}_{1} / \mathrm{VC} \%$ of less than two standard deviations of their predicted mean. ${ }^{8}$ The subjects were examined at the Chest and Allergy Institute, Tel-Aviv Medical Center, based on previous routine spirometric measurements performed elsewhere.

Initial screening excluded subjects with obvious causes for bronchial hyperreactivity including smoking, atopy, or recent viral respiratory infection. The remaining 84 subjects underwent the following measurements: (1) physical examination; (2) spirometric testing and measurement of static lung volumes using a Jaeger Masterlab and slow vital capacity measured by an expiratory manoeuvre with the best of three reproducible measurements being recorded; (3) measurement of the effect of exercise challenge on the spirometric data as previously described. ${ }^{9}$ Each patient underwent spirometric tests followed by 10 minutes running on a treadmill (Quinton) reaching 90(5)\% of maximal predicted heart rate. Spirometric testing was repeated 15 minutes later and a drop of $\geqslant 15 \%$ in $\mathrm{FEV}_{1}$ was considered significant; (4) methacholine challenge performed according to a modification of Chai's method, not using a dosimeter. ${ }^{10} \mathrm{~A}$ Devilbis (645) nebuliser delivering compressed air at a rate of 61 / min was used for inhalation challenge. Each patient inhaled increasing concentrations of methacholine $(0.07,0.15,0.3,0.6,1.5,3,6,12$, $25 \mathrm{mg} / \mathrm{ml}$ ), each of which was inhaled by five inspirations from FRC to TLC. Spirometric parameters were measured at baseline and repeated 1.5 minutes after each dose of methacholine until at least two technically correct manoeuvres were obtained; the better value was recorded. The concentration inducing a $20 \%$ drop in $\mathrm{FEV}_{1}$ was calculated from the semilogarithmic dose-response curve. The provocation was continued until the last dose in all subjects.

Each subject participated in three study 
days at the same time of the day within a two week period. On day 1 baseline pulmonary function tests and response to salbutamol were measured, on day 2 exercise challenge was performed, and on day 3 a methacholine challenge was performed. Subjects who demonstrated bronchial hyperreactivity underwent skin tests (prick) with environmental allergens (dust, mite, cockroach, mixed moulds, mixed grasses, mixed trees, dog, cat, with histamine and saline as control). These subjects also had an additional bronchial hyperreactivity evaluation by measuring peak expiratory flow rates (mini Wright) twice a day for a week.

As a control group 37 young healthy men were included in the study (group B). All were employed by the hospital and had volunteered for the study. None were smokers, and none had atopy nor recent viral respiratory infections. They all underwent the same evaluations as those in group $\mathrm{A}$.

The study was approved by our local Helsinki Ethical Committee.

\section{STATISTICAL ANALYSIS}

The data obtained from both groups (static lung volumes, flow rates, and the rates of bronchial hyperreactivity) were analysed using the Student's paired $t$ test.

\section{Results}

The subjects in group A fulfilled the criteria of having $\mathrm{FEV}_{1} / \mathrm{VC} \%<2 \mathrm{SD} \%$ predicted, while those in group B had normal spirometric values $\left(\mathrm{FEV}_{1} / \mathrm{VC} \%>2 \mathrm{SD}\right)$. The difference between the two groups was significant for $\mathrm{FEV}_{1} / \mathrm{VC} \%$ ( $\left.\mathrm{p}<0.05\right)$. All were healthy men with no history of airways disease and most participated in strenous physical activity. Simple anthropometric data of the groups are summarised in table 1 .

A summary of their baseline pulmonary function is given in table 2. Although the mean values for lung volumes (VC, FVC, TGV, and TLC) were high in group A, all were within the normal range and no significant differences were found. Salbutamol inhalation ( $1 \mathrm{ml}$ of $5 \mathrm{mg} / 2 \mathrm{ml}$ normal saline) significantly improved the baseline $\mathrm{FEV}_{1}$ (by more than $10 \%$ ) in eight of the subjects in group A (table 3 ) and in none of the control group. Treadmill running did not have any effect on spirometric parameters in either group. Methacholine induced a significant drop in $\mathrm{FEV}_{1}$ in 12 subjects from group $A$ and in three from group $B$. An interesting feature of the airway responses in both groups was the fact that at certain points all the subjects reached a plateau, after which no further drop in $\mathrm{FEV}_{1}$ was observed (figure). The rates of bronchial hyperreactivity in both groups and the shape of the doseresponse curve were not significantly different. Two of the subjects in group $A$ and one in group B had positive skin tests ( $>5 \mathrm{~mm}$ weal diameter), two to mite, and one to grass mix; they denied atopic symptoms.
Table 1 Subject characteristics

\begin{tabular}{lccccc}
\hline & Group $A$ & & \multicolumn{2}{c}{ Group $B$} \\
\cline { 2 - 3 } \cline { 6 - 6 } & Mean & Range & & Mean & Range \\
\hline Age (years) & 24 & $17-44$ & & 27 & $22-48$ \\
Height (cm) & 178 & $170-185$ & & 174 & $169-182$ \\
Weight (kg) & 75 & $60-100$ & & 76 & $62-92$ \\
\hline
\end{tabular}

Table 2 Baseline pulmonary function parameters expressed as percentage predicted

\begin{tabular}{llllll}
\hline & \multicolumn{2}{l}{ Group $A$} & & \multicolumn{2}{l}{ Group $B$} \\
\cline { 2 - 3 } \cline { 5 - 6 } & Mean & Range & & Mean & Range \\
\hline VC & 108 & $82-125$ & & 102 & $83-110$ \\
FVC & 109 & $86-130$ & & 103 & $84-108$ \\
TGV & 121 & $80-145$ & & 109 & $80-110$ \\
TLC & 107 & $81-126$ & & 103 & $83-109$ \\
RV/TLC & 115 & $91-155$ & & 106 & $92-112$ \\
TGV/TLC & 111 & $93-164$ & & 105 & $90-110$ \\
FEV $_{1}$ & 86 & $66-118$ & & 91 & $77-110$ \\
$\mathrm{FEV}_{1} /$ /V & $69 *$ & $64-73$ & & $82 *$ & $76-92$ \\
$\mathrm{MEF}_{25}$ & 62 & $25-84 \%$ & & 74 & $64-89$ \\
$\mathrm{MEF}_{50}$ & 64 & $28-83 \%$ & & 73 & $62-91$ \\
\hline
\end{tabular}

$\mathrm{VC}=$ vital capacity (slow); $F V C=$ forced vital capacity; $\mathrm{TGV}=$ thoracic gas volume; $\mathrm{TLC}=$ total lung capacity $\mathrm{RV}=$ residual volume; $\mathrm{FEV}_{1}=$ forced expiration volume in one second; $\mathrm{MEF}_{25}, \mathrm{MEF}_{50}=$ maximal expiratory flow at $25 \%$ and

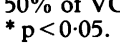

Table 3 Effect of salbutamol inhalation on pulmonary function in responders (percentage)

\begin{tabular}{lrlll}
\hline Patient no. & $V C \%$ & $F E V_{1} \%$ & $F E V_{1} / V C \%$ & $M E F_{50}$ \\
\hline 4 & -1 & 14 & 14 & 50 \\
6 & -2 & 13 & 14 & 43 \\
20 & 0 & 12 & 12 & 28 \\
25 & -2 & 17 & 20 & 53 \\
40 & -2 & 15 & 17 & 35 \\
51 & 2 & 17 & 15 & 25 \\
60 & 3 & 18 & 14 & 40 \\
72 & -2 & 13 & 15 & 33 \\
Mean & & 15 & 15 & 38 \\
SD & & 2 & 2 & 10 \\
\hline
\end{tabular}
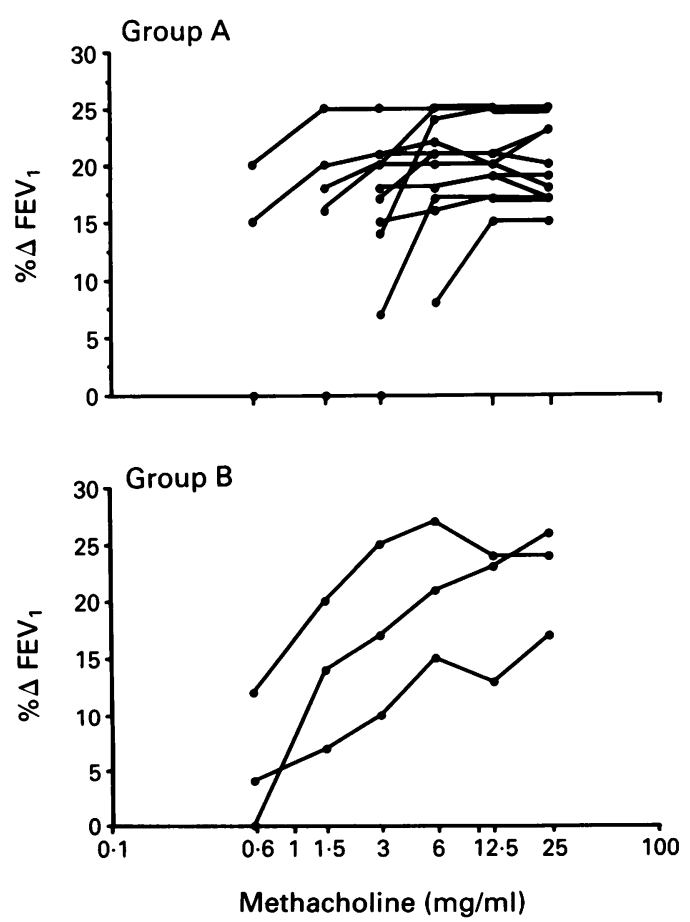

Individual methacholine dose-response curves in 12 asymptomatic subjects with low flow rates $(F E V, / V C \%)$ (group $A$ ) and in three subjects with normal flow rates (group $B$ ). 
The mean change in peak expiratory flow rate $(\triangle \mathrm{PEF} \%)$ was expressed by:

\section{$\underline{\text { PEF morning - PEF evening }}$ PEF morning}

For the nine subjects in group A who completed the test for the whole week $\triangle \mathrm{PEF}$ was 12 (3)\%; for the six subjects who had $\mathrm{PC}_{20}$ $<8 \mathrm{mg} \%$ (asthmatic range) the mean $\triangle \mathrm{PEF}$ was $17(2) \%$, and for the three who had $\mathrm{PC}_{20}$ $>8 \mathrm{mg} \%$ it was 9 (3)\%. There was a good correlation between the $\mathrm{PC}_{20}$ of the six hyperreactive subjects to the $\triangle \mathrm{PEF}(\mathrm{p}<0.05)$. The mean $\triangle \mathrm{PEF}$ for the control group was $11 \%$.

\section{Discussion}

Asymptomatic subjects found on routine screening to have significantly low $\mathrm{FEV}_{1} / \mathrm{VC} \%$ $(<2 \mathrm{SD} \%$ predicted) were evaluated for airway disease. None of the subjects had any common risk factors for developing airway disease $\mathrm{e}^{11}{ }^{12}$ or viral respiratory tract infection,,$^{13}$ and none had a first degree relative with bronchial asthma. ${ }^{14}$ Two who had bronchial hyperreactivity were also atopic upon skin testing.

In spite of the significantly low $\mathrm{FEV}_{1} / \mathrm{VC} \%$ in group $\mathrm{A}$ the other pulmonary function tests were found to be in the normal range. Following heavy exercise there was no change in $\mathrm{FEV}_{1}$ and the rate of bronchial hyperreactivity was not significantly different between the two groups. It also appears that high lung volume, as seen in a few of the subjects, did not affect the rate or the degree of bronchial hyperreactivity. As expected, the subjects with bronchial hyperreactivity also had significant fluctuation in their PEF during the day.

There are relatively few reports on the relation between non-specific bronchial hyperreactivity and pulmonary function. In these reports increased responsiveness was associated with a decreased level of pulmonary function. ${ }^{1-37}$ However, little insight was provided of this relation in healthy subjects as most studies have concentrated on selected populations such as smokers, asthmatics, bronchitics or other groups of subjects with disease. Possible selection bias and the occurrence of disease itself on other factors may therefore have affected the association between non-specific bronchial hyperreactivity and pulmonary function.

Malo et $a l^{15}$ examined 100 non-smoking volunteers who were completely free of respiratory symptoms in a cross sectional study and found that $\mathrm{PC}_{20}$ methacholine was related to the baseline $\mathrm{FEV}_{1}$. Welty et al ${ }^{16}$ studied a random population of 171 adults and found no statistically significant association between bronchial hyperreactivity (assessed by cold air challenge test) and pulmonary function after adjusting for smoking habits.

The small decrease of $\mathrm{FEV}_{1} / \mathrm{VC} \%$ in our symptomatic subjects had no effect on bronchial hyperreactivity. Interestingly, our subjects showed a particular dose-response pattern following methacholine, with a relatively small drop in $\mathrm{FEV}_{1}$, previously shown by Woolcock et al to occur in healthy subjects. ${ }^{17}$

We conclude that the low $\mathrm{FEV}_{1} / \mathrm{VC} \%$ ratios of our group of otherwise normal subjects was not associated with any evidence of disease. Bronchial hyperreactivity does not occcur more frequently in this group of subjects than in healthy controls, but when it is found a plateau of $\mathrm{FEV}_{1}$ is seen that is similar to the normal bronchoconstrictor response to methacholine and unlike that of asthmatics. Low $\mathrm{FEV}_{1} / \mathrm{VC} \%$ with normal values of $\mathrm{VC}$ in asymptomatic subjects does not merit special investigation for airway disorders.

1 American Thoracic Society. Standards for the diagnosis and care of patients with chronic obstructive pulmonary
disease (COPD) and asthma. Am Rev Respir Dis 1987;136:225-44.

2 Ramsdell JW, Nachtweg FJ, Moser KM. Bronchial hyperreactivity in chronic obstructive bronchitis. Am Rev Respir Dis 1982;126:829-32.

3 Ramsdale EH, Morris M, Roberts RS, Hargreave FE. Bronchial responsiveness to methacholine in chronic bronchitis: relationship to airflow obstruction and cold air responsiveness. Thorax 1984;39:912-8.

4 Rubinfeld AR, Pain MCF. Relationship between bronchial reactivity, airway calibre and severity of asthma. Am Rev Respir Dis 1977;115:381-7.

5 Spector SL, Kinsman RA. More implications of reactivity characteristics to methacholine and histamine in asthmatic patients. F Allergy Clin Immunol 1979;64:587-9.

6 Galver RA, McLaughlin FJ, Levison $\mathrm{H}$. The relationship between airway obstruction and bronchial hyperreactivity in childhood asthma. Ann Allergy 1987;58:45-7.

7 Ryan G, Latimer KH, Dolovich J, Hargreave FE. Bronchial responsiveness to histamine: relationship to diurnal variation of peak flow rate, improvement after bronchodilator and airway calibre. Thorax 1982;37:423-9.

8 Berglund E, Birath G, Jure JB, Grimby G, Kjellmer I. Spirometric studies in normal subjects. Acta Med Scand 1963;173:185-91.

9 Souhrada J, Kivity S. Exercise testing. In: Provocative challenge procedures: bronchial, oral, nasal and exercise. Vol II, CRC, 1983:75-101

10 Chai H, Farr RS, Froehlich LA, Mathison DA, McLean JA, Rosenthal RR, et al. Standardization of bronchial inhalation challenge procedures. $\mathcal{f}$ Allergy Clin Immunol 1975;56:323-7.

11 Sparrow D, O'Connor G, Colton T, Barry CL, Weiss ST. The relationship of non-specific bronchial responsiveness to the occurrence of respiratory symptoms and decreased levels of pulmonary function. Am Rev Respir Dis levels of pulmon

12 Peat JK, Britton WJ, Salcome CM. Bronchial hyperresponsiveness in two populations of Australian school children. Clin Allergy 1987;17:291-300.

13 Aquilima AT, Hall WJ, Douglas RG. Airway reactivity in subjects with viral respiratory tract infection. The effect of exercise and cold air. Am Rev Respir Dis 1980;112:3-10.

14 Lang DN, Hopp RJ, Bentra AK. Distribution of methacholine inhalation challenge response in a selected adult population. $\mathcal{F}$ Allergy Clin Immunol 1987;79:533-40.

15 Malo J-L, Pineau L, Cartier A, Martin RR. Reference values of the provocative concentrations of methacholine that causes $6 \%$ and $20 \%$ changes in forced expiratory that causes $6 \%$ and $20 \%$ changes in forced expiratory
volume in one second in a normal population. Am Rev vespir Dis 1983;128:8-11.

16 Welty C, Weiss ST, Tager IB, Munoz A, Becber C, Speizer FE, et al. The relationship of airways responsiveness to cold air, cigarette smoking and atopy to respiratory symptoms and pulmonary function in adults. Am Rev Respir toms and pulmonary f
Dis $1984 ; 130: 198-203$.

17 Woolcock AJ, Salome CM, Yan K. The shape of the doseresponse curve to histamine in asthmatic and normal subjects. Am Rev Respir Dis 1984;130:71-5. 